\title{
Optimization of Binocular Microscope with Micro Digital Camera for Measuring Seminiferous Tubules Epithelium Height
}

\author{
Sutriyono \\ Biology Laboratory, Faculty of Science and Technology, UIN Sunan Kalijaga, \\ Jl. Marsda Adisucipto No 1 Yogyakarta 55281, Indonesia. Tel. +62-274-540971, Fax. +62-274-519739 \\ Author correspondency: \\ sutriyono@uin-suka.ac.id
}

\begin{abstract}
Binocular microscope optimization using micro digital camera to measure seminiferous tubules epithelium of mouse testis (Mus muculus) was completed. This research was conducted at Biology Laboratory of Faculty of Science and Technology UIN Sunan Kalijaga. The purpose of this study was to determine the height of the seminiferous tubules epithelium of mouse testis using micro digital camera. A computer was connected with binocular microscope and optilab advance, then calibration of optilab advance were done on objective lens magnification at 4x,10x and 40x with 10x ocular lens. The analysis used was descriptive analysis. The mean of the seminiferous tubules epithelium height is $105.6 \mu \mathrm{m}$. Optimization on computer and binocular microscope with micro digital camera can be used to measure seminiferous tubules epithelium.
\end{abstract}

Keywords: seminiferous tubules epithelium; binocular microscope; micro digital camera; mouse testis.

\section{INTRODUCTION}

Binocular microscopes are commonly used to view microscopic objects at magnification of $4 \mathrm{x}, 10 \mathrm{x}, 40 \mathrm{x}$, $100 x$ objective lenses and of the 10x ocular lens, resulting in a maximum magnification of 1000x. The microscope can be used to measure the size of organ or cell. measurement of length or height of cells or organs can be done using micrometer slide. After the organ or cell image are taken, the measurement were done using micrometer photomicrograph at the same magnification. We can also measure the size of the cell or organ directly by using a camera in which there is a ruler menu that works to scale or measure cells or organs. There are two shortcuts in optilab, optilab viewer and raster image. Inside the optilab viewer there are tools (buttons) for image snippets (photos), video recording (for recording in video form) and successive snippets (for sequential photos). For raster image shortcuts there are facilities for enumerators (counting by marking), scale (which can be dropped freely), there is also a marking facility that can be either arrow, circle, plus sign or box, there is also a ruler button that can be used to measure Height, length or diameter of the cell or organ. Knowing the height of epithelial tissue in the seminiferous tubules is important as seminiferous tubules can be used as indicators in the process of spermatogenesis.

One of the important parameters in histology is the size of organ and cells, for example measuring the diameter of the seminiferous tubule and the height of mouse epithelium tubulus seminiferous. For microscope to be able to measure, it is required additional tools namely micro digital camera that have facilities to measure on a micron scale. Therefore, a combination of binocular microscopy with a micro digital camera can be used to measure the height of the seminiferous tubule of epithelial cells. This paper will described the optimization of binocular microscope with micro digital camera for measuring seminiferous tubule epithelium height.

\section{MATERIALS AND METHODS}

The equipment and materials used in this study are a set of PC or laptop, binocular microscope, Miconos optical advanced digital micro camera, histological slide of testis. The research was conducted in biological laboratory, Faculty of Science \& Technology UIN Sunan Kalijaga. This research began with assembling a computer or laptop with a binocular microscope and connecting a digital micro optilab advace camera. Before taking measurements, optilab advande needs to be calibrated first, ie at the magnification of the objective lens $4 \mathrm{x}, 10 \mathrm{x}$ and $40 \mathrm{x}$, so that the maximal magnification used is 400x. Objective lens calibration process begins by calibrating the smallest magnification of $4 x$, by clicking the raster image then select the open button then select the micrometer image with $4 \mathrm{x}$ magnification, then click the calibration button, the objective lens is worth $4 x$ then select the micrometer image again with $4 x$ magnification then calibration mode $4 x$ flashing, click and drag the micron and input 
the measuring value then saved. Take the same steps for $10 \mathrm{x}$ and 40x objective lens magnification. Then measurements of epithelial tubular epithelial cells testis and recording could be done. Of the many slide preparations, we selected three slide, in each slide selected three slices of testicular organ, in each slice of the testicular organ selected three seminiferous tubules, in each seminiferous tubule an epithelium cell measurement was measured three times.

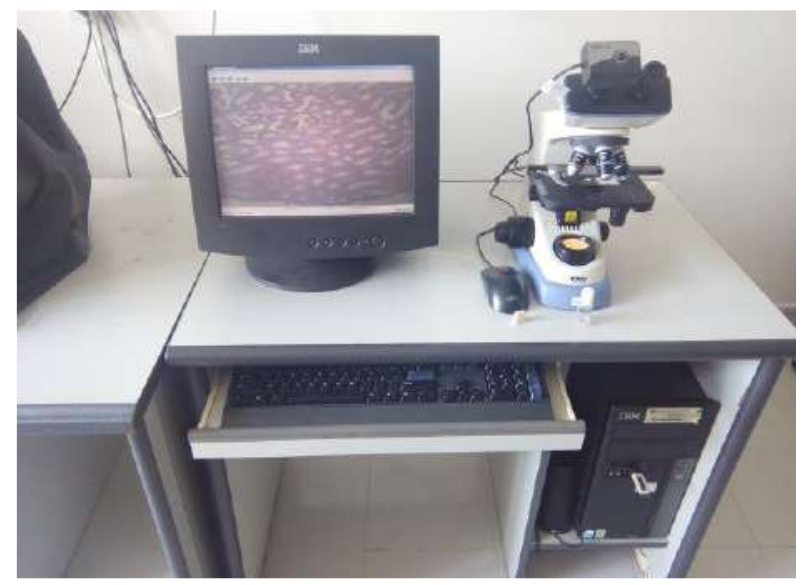

Figure 1. A set of microscope and optilab advance.

\section{RESULTS AND DISCUSSION}

Appearance of testis before measurement:

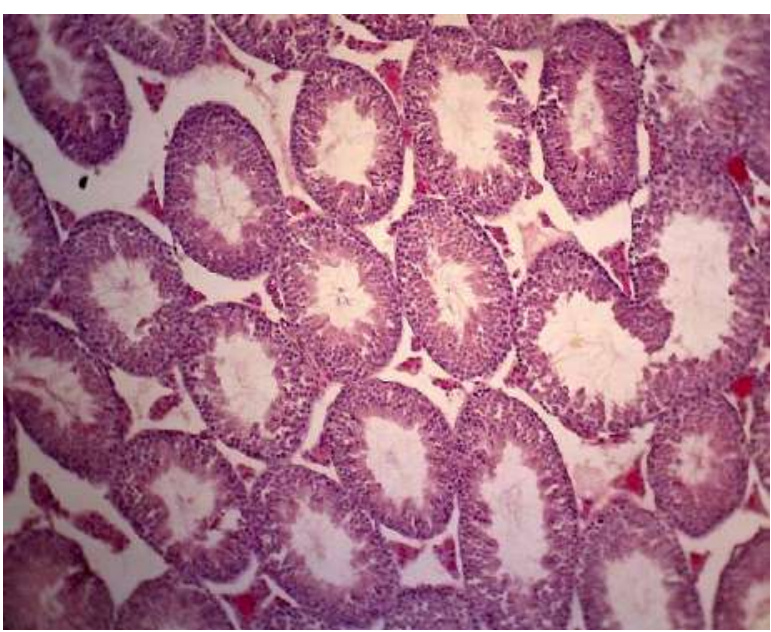

Figure 2. Mus musculus testis.10x10 magnification.

This study measured the length or height of epithelium cells in the seminiferous tubules. Prior to measurement the height of the tubular epithelium seminiferus testis, we select three intact seminiferous tubules. The corresponding cells are marked (Figure 3).

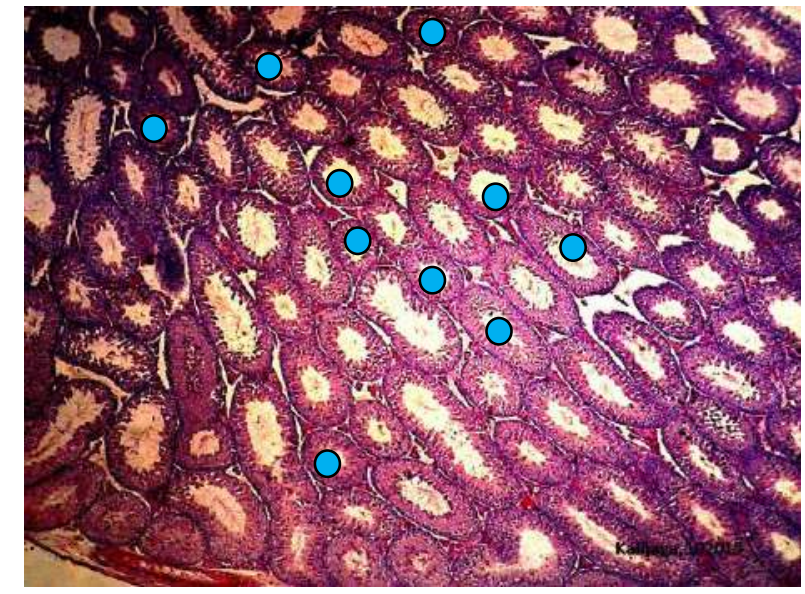

Figure 3. Marked tubulus seminiferous to be measured.

Selected tubulus seminiferuos were measured (Figure 4-Figure 9).
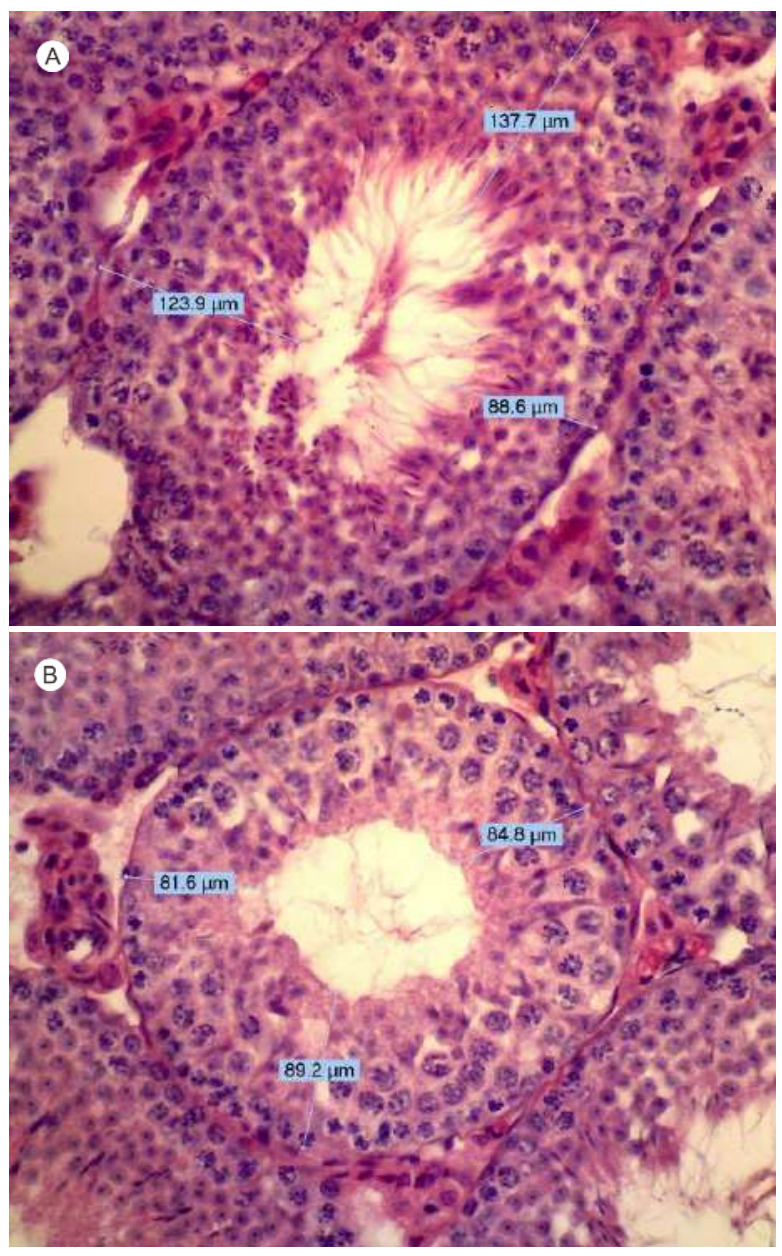

Figure 4. Measurement of the epithelium height on slide 1 tubulus 1 at 40x40 magnification resulting three values as follows: (A). 123,9 $\mu \mathrm{m}$; $137,7 \mu \mathrm{m} ; 88,6 \mu \mathrm{m}$, (B). $81,6 \mu \mathrm{m} ; 84,8 \mu \mathrm{m} ; 89,2 \mu \mathrm{m}$. 

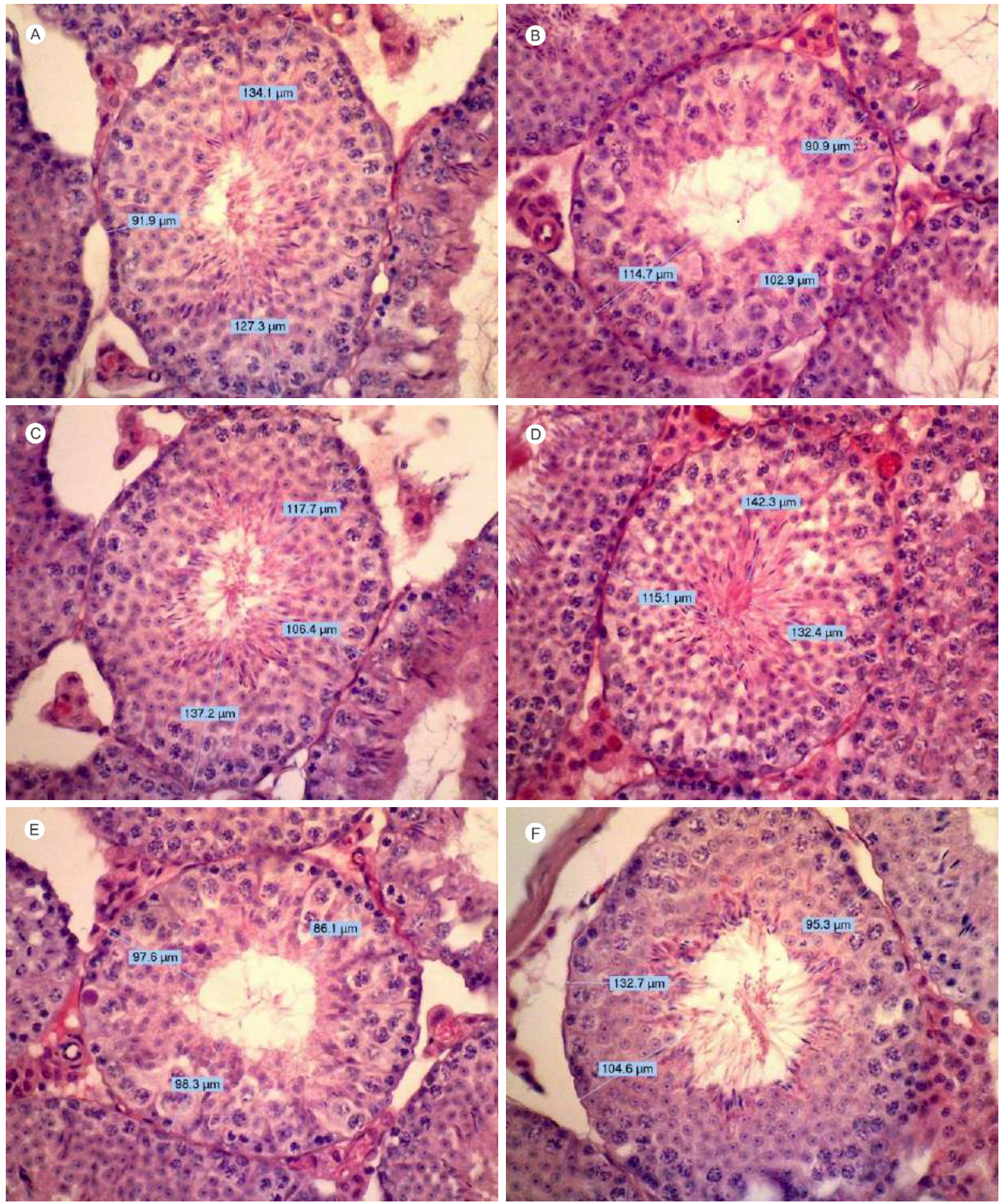

Figure 5. Measurement of the epithelium height on slide 1 tubulus 1 at $40 \times 40$ magnification resulting three values as follows: (A). $91,9 \mu \mathrm{m} ; 134,1 \mu \mathrm{m}$;

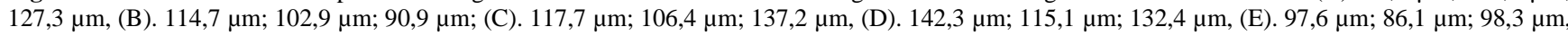
(F). $132,7 \mu \mathrm{m} ; 104,6 \mu \mathrm{m} ; 95,3 \mu \mathrm{m}$. 

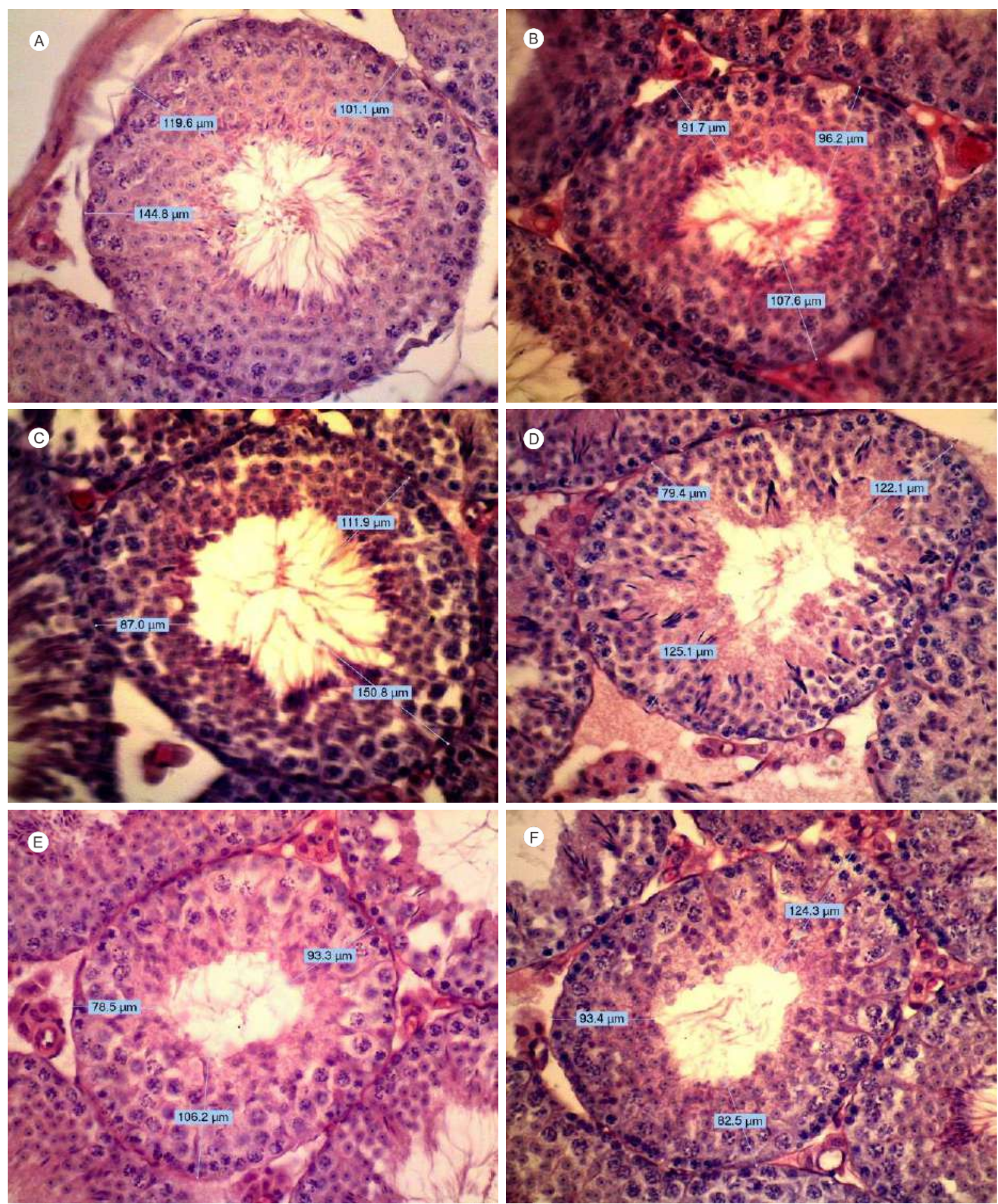

Figure 6. Measurement of the epithelium height on slide 1 tubulus 1 at 40x40 magnification resulting three values as follows: (A). 119,6 6 m; 144,8 $\mu$ m;

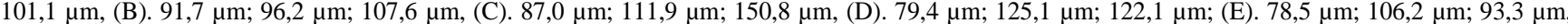
(F). $93,4 \mu \mathrm{m} ; 82,5 \mu \mathrm{m} ; 124,3 \mu \mathrm{m}$. 

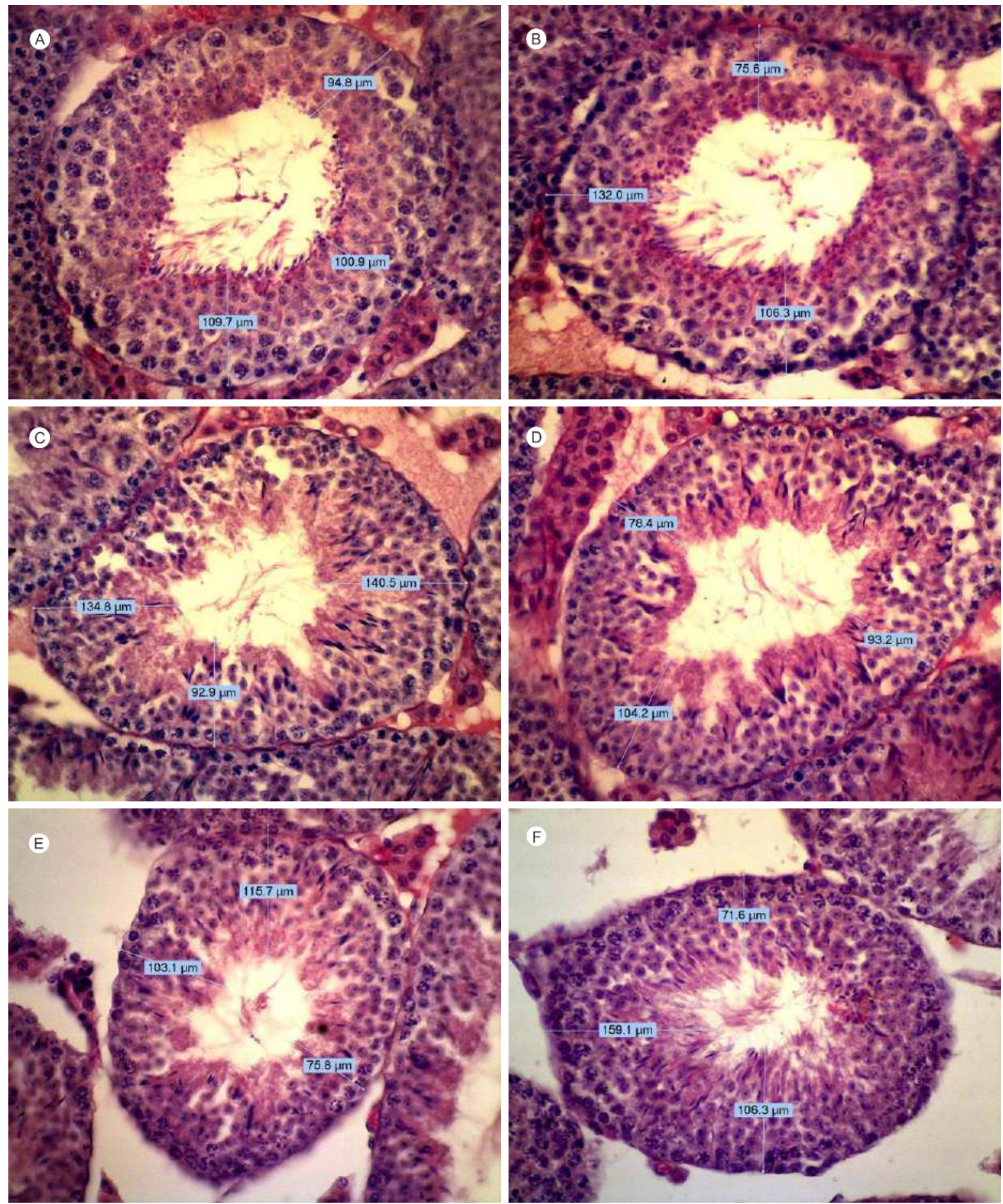

Figure 7. Measurement of the epithelium height on slide 1 tubulus 1 at $40 \times 40$ magnification resulting three values as follows: (A). $94,8 \mu \mathrm{m} ; 100,9 \mu \mathrm{m}$;

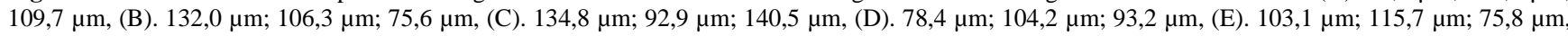
(F). $159,1 \mu \mathrm{m} ; 71,6 \mu \mathrm{m} ; 106,3 \mu \mathrm{m}$. 

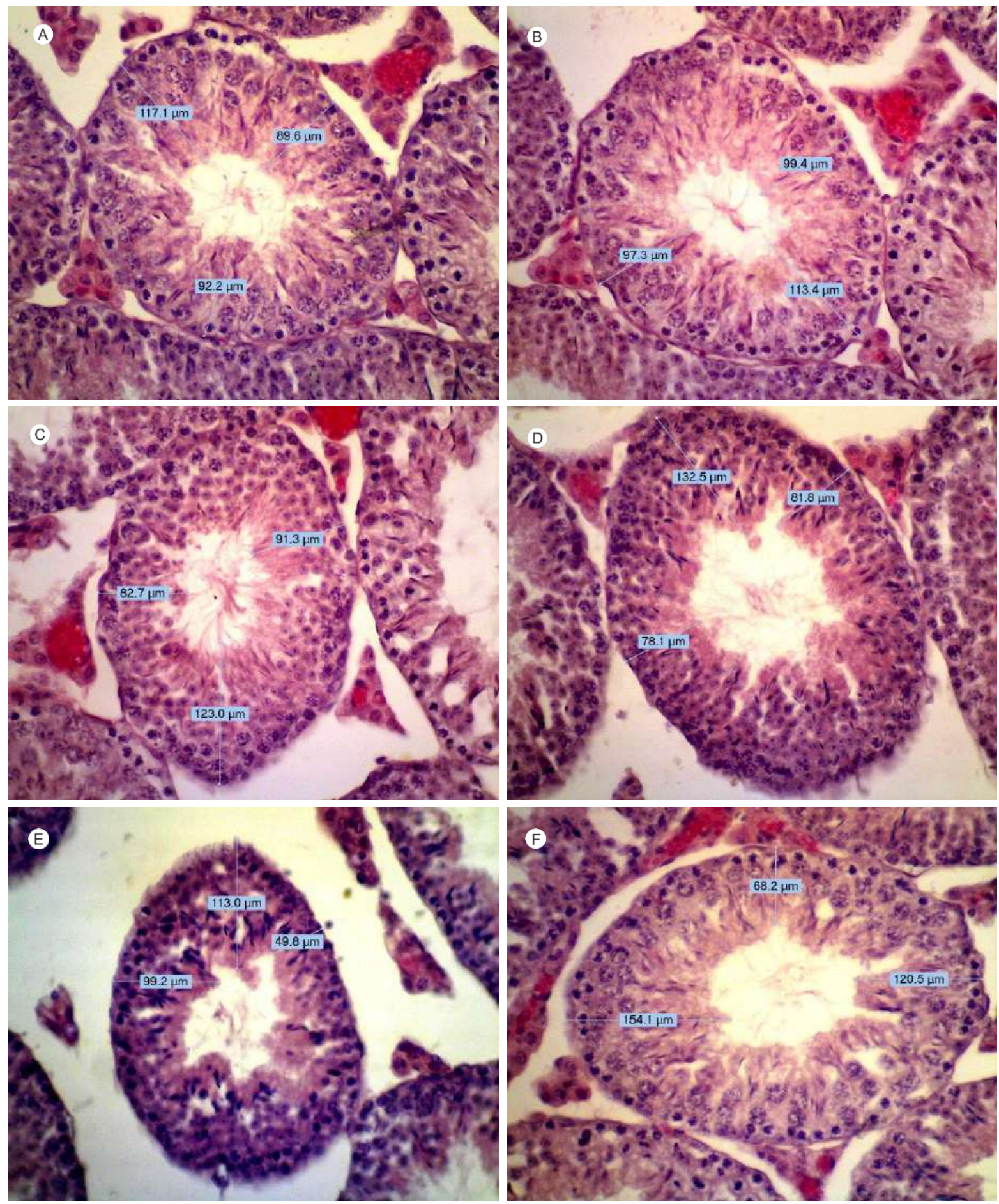

Figure 8. Measurement of the epithelium height on slide 1 tubulus 1 at $40 \times 40$ magnification resulting three values as follows: (A). $117,1 \mu \mathrm{m} ; 92,2 \mu \mathrm{m}$

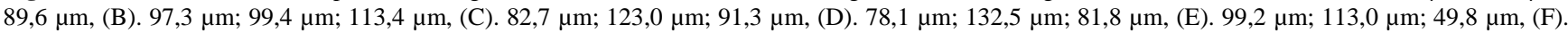
$154,1 \mu \mathrm{m} ; 68,2 \mu \mathrm{m} ; 120,5 \mu \mathrm{m}$. 


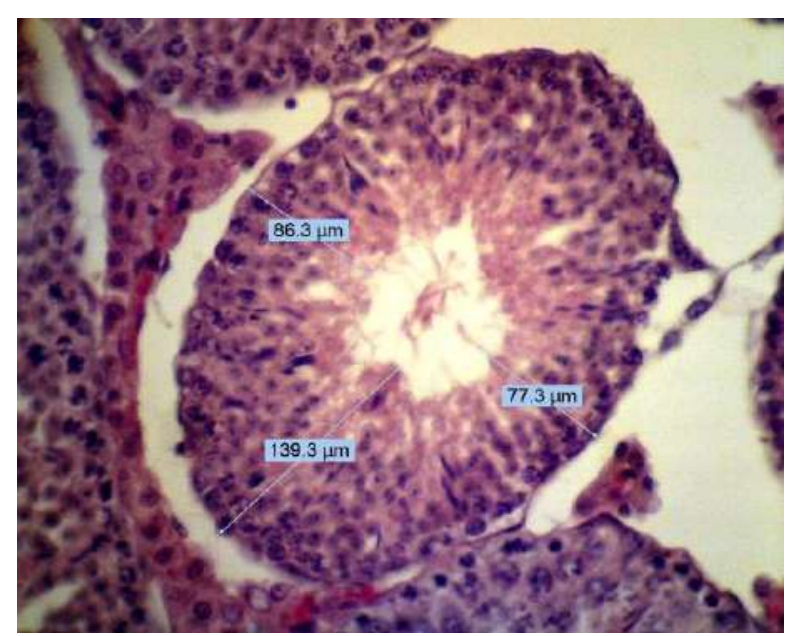

Figure 9. Measurement of the epithelium height on slide 1 tubulus 1 at 40x40 magnification resulting three values as follows: $86,3 \mu \mathrm{m} ; 139,3$ $\mu \mathrm{m} ; 77,3 \mu \mathrm{m}$.

The results of this study were data of the height of tubular epithelium seminiferous testis of mice (Mus muculus). From the measurement of eighty-one of measurement of the tubulus seminiferous epithelium, the average of the height of the tubulus seminiferous tubule epithelium was $105.6 \mu \mathrm{m}$.

\section{CONCLUSION}

The optimization of binoculer microscopy with optilab advance can be done to measure diameter of the tubulus seminiferous. The height of epithelium of tubulus seminiferous in this study was $105.6 \mu \mathrm{m}$

\section{REFERENCES}

Alatlabmiconos.co.id retrieved at 05 March 2017

Luiz R. Franca and Christiane L. Godinho. 2003. Testis Morphometry, Seminiferous Epithelium Cycle Length, and Daily Sprem Production in Domestic Cats (Felis catus). Biology or Reproduction. Federal University of Minas Gerais, Brazil

Rizka Arifianti. 2013. Berat Testis dan Struktur Histologi Testis Mencit (Mus musculus L.) Akibat Paparan Kebisingan. Skipsi. Universitas Lampung. Lampung.

Reza Anindita dkk. 2009. Diameter dan Tebal Lapisan Tubulus Seminiferus Serta Bobot Testis Mencit (Mus muculus) Setelah Pemberian Tauge Kacang Hijau (Vigna Radiata). Laboratorium Biologi. Universitas Diponegoro Semarang.

Sutriyono. 2015. Optimasi Mikroskop Binokuler Dengan Menggunakan Optilab Advance Untuk Mengukur Diameter Organ Testis Mencit (Mus muculus). Integrated Lab Journal. Universitas Islam Negeri Sunan Kalijaga Yogyakarta.

Tri Suciati dkk. 2012. Pengaruh Likopen Terhadap Gambaran Tubulus Seminiferus dan Kualitas Sperma Mencit (Mus muculus) yang Terpapar Asap Rokok. Fakultas Kedokteran Universitas Sriwijaya Palembang.

Tri Widjatmaka dan Sonki Prasetya, "Perancangan dan Pembuatan Peralatan Laboratorium Pengkonversi Gambar Struktur Mikro dari Mikroskop ke komputer Sebagai Sarana Praktikum Metalografi”. jurnal Politeknologi. 10 (3).

Tung Yang Wing and Kent Christensen. 1982. Morphometric Studies on Rat Seminferous Tubules. The American Journal of Anatomy. The University of Michigan. 
THIS PAGE INTENTIONALLY LEFT BLANK 